\title{
Molecular Detection of Staphylococcus aureus Enterotoxin A and B Genes in Clinical Samples from Patients Referred to Health Centers in Zahedan City
}

\author{
Mohammad Bokaeian ${ }^{1}$, Saeide Saeidi ${ }^{2}$, Mehdi Hassanshahian ${ }^{3 *}$ \\ ${ }^{1}$ Infectious Diseases and Tropical Medicine Research Center, Zahedan University of Medical Sciences, Zahedan, Iran. \\ ${ }^{2}$ Zabol Medicinal Plant Research Center, Zabol University of Medical Sciences, Zabol, Zabol, Iran. \\ ${ }^{3}$ Department of Biology, Faculty of Sciences, Shahid Bahonar University of Kerman, Kerman, Iran.
}

\section{Received: 17 Jan 2016}

Revised : 13 Feb 2016

Accepted: 28 Feb 2016

Corresponding Author:

Mehdi Hassanshahian

Address: Department of Biology,

Faculty of Sciences, Shahid Bahonar

University of Kerman, Kerman, Iran.

Phone: +989132906971

E-mail: hasanshahi@gmail.com

\begin{abstract}
Background: In this study we aimed at detecting the enterotoxin A and B gene of $S$. aureus in clinical samples of patients attending health centers in Zahedan using molecular methods.

Materials and Methods: A cross-sectional study was carried out in which 40 samples of $S$. aureus were obtained from patients in a hospital in Zahedan, Iran. Following the biochemical tests, Identifications were confirmed by PCR with specific primers.

Results: Among 40 clinical isolates of S.aureus the frequency of sea gene was $2 \%$ and the frequency of seb gene was $8 \%$ while the frequency of both sea+seb genes was $3 \%$.

Conclusion: Enterotoxin of $S$. aureus is one of the main factors in the pathogenesis of various diseases and production of these toxins increase the incidence of diseases, so rapid treatment is needed for enterotoxin gene expression.
\end{abstract}

Keywords: Enterotoxin; Food Poisoning; Staphylococcus aureus; Gene

Please cite this article as: Bokaeian M, Saeidi S, Hassanshahian M. Molecular Detection of Staphylococcus aureus Enterotoxin A and B Genes in Clinical Samples from Patients Referred to Health Centers in Zahedan City. Res Mol Med. 2016; 4 (2): 44-46

\begin{abstract}
Introduction
Staphylococcal exotoxins from more than 20 different staphylococcal and streptococcal family, that is performance related and share sequence similarity. This bacterial protein known to cause fever and significant human diseases, including food poisoning and toxic shock syndrome is connected. The toxins produced by Staphylococcus aureus are for the most part although other species also been shown that enterotoxigenic. (1).

Most genes coding for positions on the mobile elements such as plasmids, bacteriophages or pathogenicity islands located. Thus, horizontal transfer between species is rare. In fact, a recent study showed that the majority of Staphylococcus aureus isolates obtained from three separate hospitals more than one enterotoxin (2). The most common staphylococcal enterotoxins SEA and SEB. SEA toxin commonly associated with food poisoning Staphylococcus. SEB, while it is associated with food poisoning, has been studied for potential use as a
\end{abstract}

bioweapon inhalation (3). The aim of this study was to detect enterotoxin A and B genes of $S$. aureus in clinical samples of patients attending a hospital in Zahedan, Iran using molecular methods.

\section{Materials and Methods}

40 samples from 300 persons were collected from a hospital in Zahedan. The samples were quarterly collected from infected men. Ten microliters of each sample were cultured on blood agar. Isolated Gram and catalase positive cocci were further tested for biochemical characterization. Following the biochemical test, Staphylococcal isolates were identified using species- specific gene amplification (16 S DNA, Toxin A, Toxin B). Two pair primers used for PCRs are shown in Table1. The total volume of the reaction mixture $(25 \mu \mathrm{l})$, included $2 \mu \mathrm{l}$ of dNTP (200 $\mu \mathrm{l}, 2.5 \mu \mathrm{l}$ of $10 \mathrm{X}$ Taq buffer containing $15 \mathrm{~m} \mu$ $\mathrm{Mgcl}_{2}, 1 \mu \mathrm{l}$ of each oligonucleotide forward and reverse primers $(10 \mathrm{pm} / \mu \mathrm{l}), 0.35 \mu \mathrm{l}$ of Taq DNA 
Polymerase $(3 \mathrm{u} / \mu \mathrm{l}), 1 \mu \mathrm{l}$ DNA $(30 \mathrm{mg} / \mu \mathrm{l})$ and distilled water $(17.2 \mu \mathrm{l})$. Pair primer 1 amplified a $270 \mathrm{bp}$ PCR product in the PCR reaction. Pair primer 2 amplified a 477 bp PCR product in the PCR reaction (6). All experiments and measurements were repeated at least three times. Statistical analyses were performed using SPSS and Excel 2010.

Table 1. Primer sequences to identify enterotoxin A and B.

\begin{tabular}{llll}
\hline Gene & Primer & Sequence & Product size (bp) \\
\hline \multirow{2}{*}{ SEA } & SEAf & TGT ATG TAT GGA GGT GTA AC & 270 \\
& SEA r & ATT AAC CGA AGG TTC TGT & 477 \\
\multirow{2}{*}{ SEB } & SEB $\mathrm{f}$ & TCG CAT CAA ACT GAC AAA CG & \\
& SEB $\mathrm{r}$ & GCA GGT ACT CTA TAA GTG CC & \\
\hline
\end{tabular}

\section{Ethics Statement}

The study was approved by the Shahid Bahonar University of Kerman Ethics Committee.

\section{Results}

In this investigation, 300 samples were obtained from 300 healthy carriers, of which 40 samples of $S$. aureus were detected biochemically. To detect $S$. aureus types $a, b$ enterotoxins a total of $40 \mathrm{~S}$. aureus strains originating from healthy carriers was tested for enterotoxin production by PCR assay. The specificity of PCR was tested for positive and negative control strains. The six SE-encoding genes (sea, seb) were detected in the positive control strains and not in the negative control strains (Figure 1).

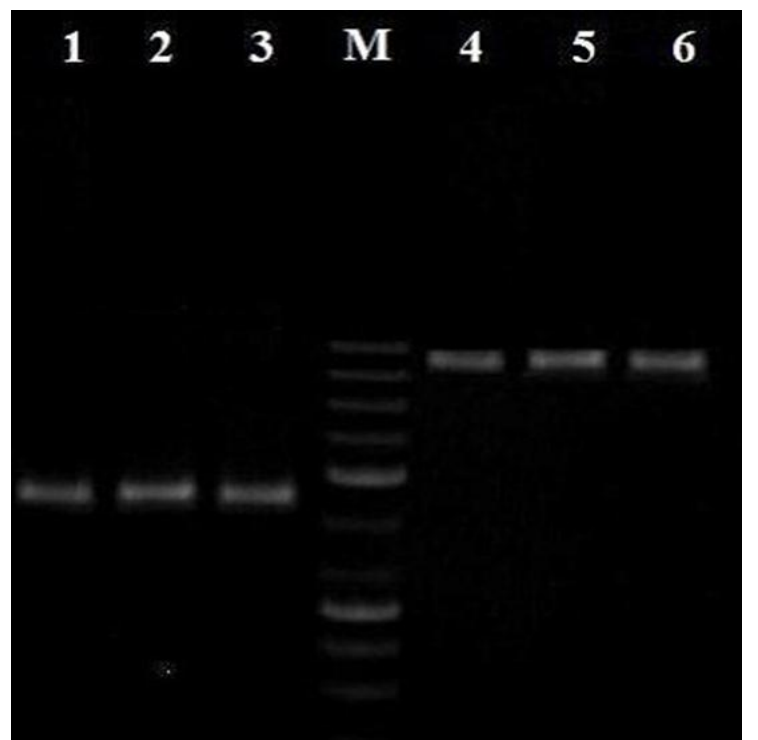

Figure 1. Gel analysis of PCR-amplified toxin gene sequences. Lanes 1, 2, 3 SEA (270bp) and lane 4, 5, 6 SEB (477bp).

Furthermore, 270 and $477 \mathrm{bp}$ segments were related to the amplification of a specific fragment of gene sea and seb that is responsible for enterotoxin type A and B and $270 \mathrm{bp}$ for staphylococcal enterotoxin A gene (sea) (Figure 1, lane 1, 2, 3), and 477 bp for staphylococcal enterotoxin B gene (seb) (Figure 1, lane 4, 5, 6) Results showed that $24(2 \%)$ isolates were associated with the sea gene, $15(8 \%)$ isolates were associated with the seb gene. Only one of these $3 \%$ of the isolates harbored sea and seb.

\section{Discussion}

In this study the prevalence of toxins produced was low but enterotoxin A had highest prevalence. Today to determine the mechanism and role of enterotoxin and determine its specific receptors great deal of research was done or is being done. Therefore, rapid diagnosis of Enterotoxigenic by standard methods is very important.

Chiang et al. showed that $1.48 \%$ of $S$. aureus strains contain the gene encoding for sea. Most isolated type was staphylococcal enterotoxin A (6.28\%) strains (7). Adwan et al. showed that $37 \%$ of $S$. aureus isolates containing the gene encode for enterotoxin type A (8). The results in Anvari et al. showed that $74 \%$ of the samples have enterotoxin A (9).

S. aureus samples isolated from Motahari Hospital, Tehran showed that of 100 samples of S. aureus clinical isolates had $12 \%$ of enterotoxin $\mathrm{A}, 1 \%$ of enterotoxin $\mathrm{B}$ and $1 \%$ enterotoxin $\mathrm{A}$ and $2 \%$ of enterotoxins A and B (10). Nashev et al. reported the most abundant enterotoxin is enterotoxin A $(23 \%)$ in $S$. aureus isolates from nasal samples (11).

The most common enterotoxin coding gene in their study was sea with a prevalence of $33 \%$, followed by sec with $15 \%$ prevalence (12). A Turkish investigation showed that only $2.9 \%$ of $70 \mathrm{~S}$. aureus strains tested were positive for sea gene while there were no positive results for other putative genes $(13,14,15,16)$.

\section{Conclusion}

Given the role of enterotoxin in the pathogenicity of $S$. aureus and nosocomial infections in this study, patients can be considered as a source of emissions in the hospital and enterotoxins $\mathrm{A}$ and $\mathrm{B}$ also play important roles in infectious diseases.

\section{Acknowledgments}

We would like to thank all individuals who collaborated 
and helped us to complete this project.

\section{Author contributions}

All author of this article have same contribution for doing this project.

\section{Conflict of Interest}

The authors declare no conflict of interest.

\section{Support/Funding}

This work was financially supported by Zabol University of Medical Sciences and Shahid Bahonar university of Kerman.

\section{References}

1. Dinges MM, Dinges P, Orwin M. Exotoxin of staphylococcus aureus. Clin Microbiol Rev 2000; 13(1): 16-34. PMID: 10627489

2. Saadati M, Barati B, Doroudian M, Shirzad H, Hashemi M , Hosseini SM, et al. Detection of Sea, Seb, Sec, Seq genes in staphylococcus aureus isolated from nasal carriers in Tehran province, Iran; by multiplex PCR. JPS. 2011; 2(2).

3. Madahi H, Rostami F, Rahimi E, Safarpoor Dehkordi F. Prevalence of Enterotoxigenic Staphylococcus aureus Isolated From Chicken Nugget in Iran. Jundishapur J Microbiol. 2014; 7(8): e10237

4. Hoseini Alfatemi SM, Motamedifar M, Hadi N, Sedigh Ebrahim Saraie H. Analysis of Virulence Genes Among Methicillin Resistant Staphylococcus aureus (MRSA) Strains. Jundishapur J Microbiol. 2014; 7(6): e10741.

5. Asadollahi P, Delpisheh A, Maleki MH, Azizi Jalilian F, Alikhani MY, Asadollahi K, et al. Enterotoxin and Exfoliative Toxin Genes Among Methicillin-Resistant Staphylococcus aureus Isolates Recovered From Ilam, Iran. Avicenna J Clin Microb Infec. 2014; 1(2).

6. Sarrafzadeh Zargar MH, Hosseini Doust R, Mohebati A Staphylococcus aureus Enterotoxin A Gene Isolated From Raw Red Meat and Poultry in Tehran, Iran. Int J Enteric Pathog. 2014; 2(3): e16085.

7. Chiang YC, Chang LT, Lin CW, et al. PCR primers for the detection of staphylococcal enterotoxins K, L, and M and survey of staphylococcal enterotoxin types in Staphylococcus aureus isolates from food poisoning cases in Taiwan. J Food Prot. 2006; 69: 10729. PMID: 16715807
8. Adwan G, Abu-Shanab B, Adwan K. Enterotoxigenic Staphylococcus aureus in raw milk in the north of Palestine. Turk J Biol. 2005; 29: 229-32.

9. Anvari SH, Sattari M, Forozandehmoghadam M, Najarpeerayeh SH, Fouladi I. Detection of staphylococcus aureus entrotoxin A to E from Clinical sampel by PCR. Res J Biological Sci. 2008; 3: 826-9.

10. Gadyary F, Stari M, Iran MA, James R., nature sphere Q, pour Quli L. Tracking enterotoxins A, B, C and D S. aureus clinical strains isolated from patients in hospital burn Motahari Tehran. J Med Microbiol. 1390: (5) 5: 27-20.

11. Nashev D, Toshkova K, Bizeval L, Akineden O, La"mmler C, Zscho"ck M. Distribution of enterotoxin genes among carriageand infection-associated isolates of Staphylococcus aureus. Lett Appl Microbiol. 2007; 45(6): 681-685.

12. Wang LX, Hu ZD, Hu YM, Tian B, Li J, Wang FX, et al. Molecular analysis and frequency of Staphylococcus aureus virulence genes isolated from bloodstream infections in a teaching hospital in Tianjin, China. Genet Mol Res. 2013; 12(1):646-54. PMID: 23546946

13. Gencay YE, Ayaz ND, Kasımoglu-Dogru A. Enterotoxin gene profiles of Staphylococcus aureus and other Staphylococcal isolates from various foods and food ingredients. Erciyes Üniversitesi Veteriner Fakültesi Dergisi. 2010; 7(2):75-80.

14. Erfanimanesh S, Eslami G, Goudarzi H, Taherpour A, Hashemi A, Taki E. In vitro evaluation of capsaicin inhibitory effects on zonula occludens toxin in vibrio cholerae ATCC14035 strain. Res Mol Med. 2014; 2 (4):33-35.

15. Solimani P, Salari S, khalizadeh S, Hassanzad M, Khodavaisy $\mathrm{S}$, Abastabar M, et al. Use of PCR-RFLP and PCR-HWP1 for identification of Candida species isolated from cystic fibrosis patients. Res Mol Med. 2014; 2 (3):24-28.

16. Sadeghi S, Tabatabaeian H, Hojati Z. Optimization of Real Time PCR for Precise Measurement of HER2 Overexpression in Breast Cancer Specimens. Res Mol Med. 2015; 3 (2):37-44. 